\title{
ЕФЕКТИВНЕ ВИКОРИСТАННЯ ОБОРОТНИХ АКТИВІВ ПІДПРИЄМСТВОМ
}

\author{
Терещенко Світлана Іванівна. \\ доктор економічних наук, доцент \\ Сумський національний аграрний університет \\ ORSID 0000-0001-7901-1308 \\ s.i.terechenko@gmail.com \\ Федай Валерій Володимирович \\ магістр \\ Сумський національний аграрний університет
}

В сучасних умовах господарювання кожне підприємство робить головний акцент на вирішенні питань стабільності функціонування та максимізації прибутку. Для того, щоб досягти поставлених цілей, потрібна правильно підібрана, чітка та ефрективна політика управління активами підприємства, в яких значну роль відіграють оборотні кошти. Актуальність досліджуваної проблеми управління оборотними коштами зумовлена також тим, що від ефективності їх формування, регулювання та використання залежить оптимальність рівня ліквідності, платоспроможності, i, як наслідок, фінансової стійкості підприємства. Брак оборотних коштів ставить підприємство на шлях банкрутства, що змушує задуматись над удосконаленням системи управління ними. Нестача грошових коштів, так і їх надлишок чинять значний вплив на роботу підприємства, спричиняючи збої в виробництві чи постачанні сировини, чим зменшують очікуваний прибуток. Саме тому дуже важливим є прискорення залучення грошових оборотних коштів як із внутрішніх, так і з зовнішніх джерел. Кваліфріковане управління грошовими коштами дає можливість зацікавленим особам (зовнішнім і внутрішнім користувачам) приймати певні оптимальні управлінські рішення, які в майбутньому можуть суттєво вплинути на кінцевий результат фінансово-господарської діяльності підприємства

Ключові слова: активи, фрінансові результати, оборотні активи, оборотні кошти, оборотні засоби, робочий капітал, джерела фінансування.

DOI: https://doi.org/10.32845/bsnau.2019.2.13

Постановка проблеми. Величина активів підприємства залежить від обсягу фінансових ресурсів, якими воно володіє. Структура покриття активів джерелами формування безпосередньо впливає на фінансовий стан підприємства. Оптимально сформовані активи, за рахунок певної структури фінансових ресурсів, дозволяють підприємству безперервно здійснювати свою діяльність, підтримувати на достатньому рівні свою платоспроможність, а також мати певний резерв коштів для швидкого реагування у непередбачуваних ситуаціях, коли раптово настане необхідність сплачувати свої борги. Тому тема дослідження є актуальною.

Аналіз останніх досліджень та публікацій. Вагомий внесок в дослідження питань управління оборотними коштами зробили такі вчені як С.М. Онисько та П.М. Марич, які дослідили систему формування та джерела фінансування оборотних коштів. І.О. Бланк розробив чіткі етапи управління оборотними активами та підходи, як до управління оборотними коштами, так і їх елементами. Г.В.Савицька розробила систему показників, необхідних для дослідження ефективності використання оборотних активів та визначила фактори, які на них впливають. В.В.Ковальов представив моделі управління оборотними коштами залежно від джерел їх формування. Питання моделювання процесів управління оборотними коштами підприємства розглядаються у працях B.І. Борзенко, О.О. Демьохіна, Т.В. П'ятак. Серед сучасних вчених проблеми, пов'язані з визначенням сутності, класифікації, формуванням та управлінням оборотними активами вивчають вітчизняні й зарубіжні вчені: І.Т. Балабанов, Е.В. Бикова, Р. Брейлі, Є.Ф. Брігхем, Дж.К. Ван Хорн, В.М. Гриньова, М.В. Гридчина, П. Етрілл, О.В.Клименко, П.В. Круш, В.О. Коюда, М.Н. Крейнина, Л.О. Коваленко, В.В. Ковалев, С. Майерс

П.М. Марич, С.М. Онисько, В.І. Подвігіна, Л.М. Ремньова, Т. Скоун, Є.С. Стоянова, А.В. Череп, Г.О. Швиданенко, Н.В. Шевчук, та ін.

Мета статті - розробка і аналіз ефективності використання оборотних коштів і пропозиції з поліпшення їх використання

Виклад основного матеріалу. Діяльність суб'єктів господарювання щодо створення та реалізації продукції здійснюється в процесі поєднання основних виробничих фондів, оборотних фондів і самої праці Безперервність процесу виробничої та комерційної діяльності потребує постійного інвестування коштів у ці елементи для здійснення розширеного їхнього відтворення. На відміну від основних виробничих фондів оборотні фонди споживаються в одному виробничому циклі і їхня вартість повністю переноситься на вартість виготовленої продукції. При цьому одна їхня частина в речовій формі входить у створений продукт і набирає товарної форми, в якій iї буде використано споживачем. Інша частина також повністю споживається в процесі виробництва, але, втрачаючи свою споживну вартість, у речовій формі в продукт праці не входить (паливо).

В таблиці 1. надано оцінку складу та структури підприємства. В 2018 р. п о відношенню до 2015 р. запаси збільшилися в 3,1 рази. Таке збільшення відбулося за рахунок нереалізованої готової продукції та незавершеного виробництва . Цей факт для підприємства є не зовсім позитивним, оскільки було б доцільним створити відділ маркетингу або логістики які займалися б тільки реалізацією продукції. Оскільки нереалізована продукція це додаткові витрати на її зберігання та недоотриманий прибуток на кінці виробничого циклу. 
Таблиця 1..- Оцінка складу та структури оборотних коштів підприємства

\begin{tabular}{|c|c|c|c|c|c|c|c|c|c|c|}
\hline \multirow{2}{*}{ Оборотні засоби } & \multicolumn{2}{|c|}{2015} & \multicolumn{2}{|c|}{2016} & \multicolumn{2}{|c|}{2017} & \multicolumn{2}{|c|}{2018} & \multicolumn{2}{|c|}{ Зміни } \\
\hline & ТИс.Грн & $\%$ & Тис.грн & $\%$ & тис.грн & $\%$ & Тис.грн & $\%$ & тис.грн & $\%$, pa3 \\
\hline Запаси, в т.ч. & 5698 & 27,29 & 9612 & 47,05 & 12956 & 32,52 & 18010 & 48,04 & +12312 & $3,1 p$ \\
\hline виробничі запаси & 1703 & 8,16 & 929 & 4,55 & 2039 & 5,12 & 1033 & 2,76 & -670 & 6,0 \\
\hline незавершене виробництво & 3623 & 17,35 & 5575 & 27,29 & 7567 & 18,99 & 5672 & 15,13 & +2049 & 1,5 \\
\hline готова продукція & 372 & 1,78 & 3108 & 15,21 & 3350 & 8,41 & 11305 & 30,15 & +10933 & 3,0 \\
\hline Поточні біологічні активи & 1186 & 5,68 & 1273 & 6,23 & 1438 & 3,61 & 2982 & 7,95 & +1796 & 2,5 \\
\hline $\begin{array}{l}\text { Дебіторська заборгованість за товари, } \\
\text { роботи, послуги }\end{array}$ & 8968 & 42,95 & 517 & 2,53 & 7375 & 18,51 & 6856 & 18,29 & -2112 & 7,6 \\
\hline Поточні фінансові інвестиції & 2666 & 12,77 & 8933 & 43,72 & 9493 & 23,83 & 9493 & 25,32 & +6827 & 3,6 \\
\hline Грошові кошти та їх еквіваленти & 2081 & 9,97 & 26 & 0,13 & 8563 & 21,49 & 130 & 0,35 & -1951 & 6,25 \\
\hline Готівка & - & - & 2 & 0,01 & - & - & - & - & - & - \\
\hline Інші оборотні активи & 279 & 1,34 & 68 & 0,33 & 19 & 0,05 & 19 & 0,05 & -260 & 6,81 \\
\hline Оборотні активи всього & 20878 & 100,00 & 20431 & 100,00 & 39844 & 100,00 & 37490 & 100,00 & +16612 & 1,8 \\
\hline
\end{tabular}

Джерело: власні розрахунки автора

В 2018 р по відношенню до 2015р відбулося збільшення поточних біологічних активів майже в 2,5 рази. Таке збільшення відбулося за рахунок купівлі молочних корів для збільшення молочного поголів'я з метою отримання прибутку. За період що аналізується підприємство збільшило поточні фінансові інвестиції майже в 3,6 разів. Цей факт свідчить про те що підприємство збільшує обсяги виробництва продукції, а це в свою чергу буде впливати на прибутковість діяльності підприємства. Склад та структура оборотних активів в цілому відповідає специфріці діяльності підприємства.

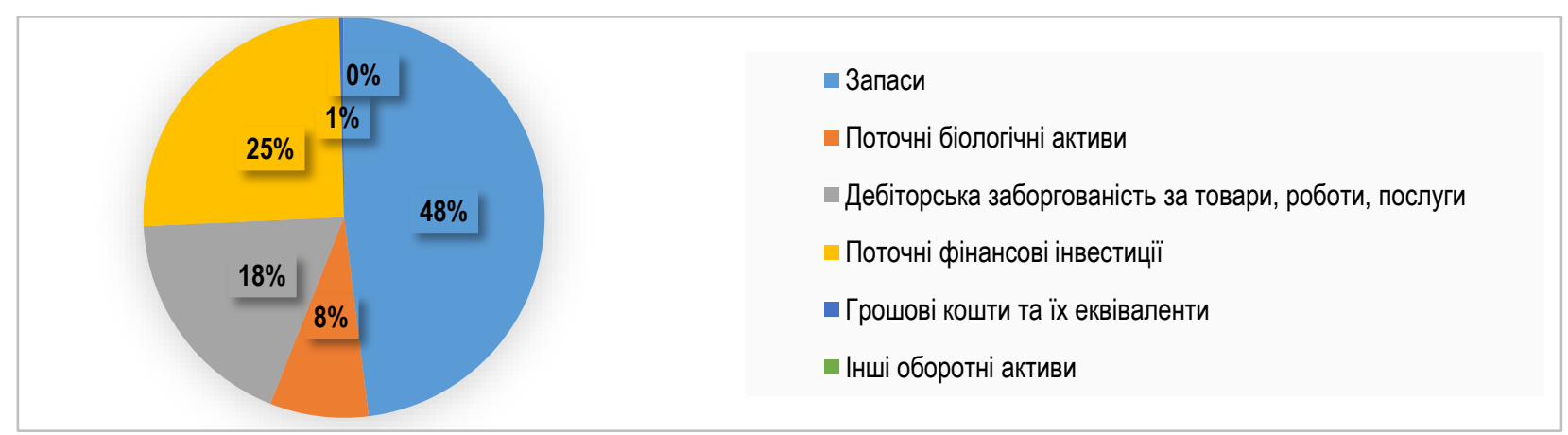

Рис 1 .- Структура оборотних коштів підприємства за 2018 р., тис. грн.

Наявність у сільськогосподарського підприємства достатніх оборотних коштів, оптимальної структури є необхідна передумова для його нормального функціонування та фінансової стійкості. Все зазначене вище, проілюструємо у наступній діаграмі.

Власні оборотні кошти це кошти, що постійно знахо- дяться в розпорядженні підприємства і сформовані за рахунок власних ресурсів (прибуток і ін.). У процесі руху власні оборотні кошти можуть заміщатися коштами, що $є$ по суті частиною власних, авансованих на оплату праці, але тимчасово вільними (у зв'язку з одноразовістю виплати заробітної плати).

Таблиця 2. - Оцінка власних оборотних засобів (робочого капіталу) підприємства.

\begin{tabular}{|l|c|c|c|c|c|}
\hline \multicolumn{1}{|c|}{ Показники } & 2015 & 2016 & 2017 & 2018 & зміни \\
\hline 1.Вартість оборотних активів & 20878 & 20431 & 39844 & 37490 & 16612 \\
\hline 2.Поточні зобов'язання & 9497 & 6656 & 18277 & 12989 & 3492 \\
\hline 3.Робочий капітал (наявність власних оборотних коштів) & 11381 & 13775 & 21567 & 24501 & 13120 \\
\hline 4. Коефіцієнт забезпеченості власними оборотними коштами & 0,545 & 0,674 & 0,541 & 0,653 & 0,108 \\
\hline 5. Коефіцієнт забезпеченості запасів і затрат & 3,785 & 2,549 & 1,665 & 1,360 & $-2,425$ \\
\hline
\end{tabular}

\section{Джерело: власні розрахунки автора}

В таблиці 2. відображено зміну коефіцієнту забезпеченості власними оборотними коштами яка становить 0,108, що означає його зростання у 2018 році в порівнянні з 2015 роком. Коефіцієнт забезпеченості запасів і затрат це співвідношення показує, що всі запаси повністю покриваються власними оборотними коштами і кредитами під товарно-матеріальні цінності, у 2017 році він становить 3,785, а у 2018 році на 2,425 менше.

В умовах інтеграції України в міжнародний економічний простір особливого значення набуває підвищення ефек- тивності використання оборотних активів, що забезпечить виконання поставлених перед підприємством задач з мінімальною їх сумою. Від ефективності використання оборотних активів залежить фінансовий стан підприємства, прискорення оборотності активів зумовлює не тільки фінансову стійкість, платоспроможність підприємства, а й перспективи його подальшого економічного зростання.

Одним з найважливіших для аналізу є показник оборотності, який водночас відображає обсяг реалізації продукції за даний період та ефективність використання матеріальних засобів і коштів. Навіть враховуючи сезонність виробництва 
в сільському господарстві, зростання терміну свідчить про уповільнення обороту оборотних активів та необхідність залучення додаткових коштів для їх формування і відповідно погіршує показники платоспроможності підприємства. Так, середньорічна вартість оборотних коштів в 2018 році по відношенню до 2015 року збільшилась на 16,6 млн. грн.. Це збільшення відбулось за рахунок збільшення виробничих оборотних засобів. Цей факт для підприємства свідчить про те що підприємство вишукує можливості для збільшення обсягів виробництва продукції. Але нажаль збільшення кількості готової продукції яка не реалізовується є дійсно проблемою для підприємства. Оскільки підприємство ефективно використовує свої оборотні засоби свідчить коефіцієнт оборотності оборотних засобів, який коливається в межах від 0,93 0,96.Завдяки ефективному використанню оборотних коштів підприємство отримує 58 коп. валової продукції, 23 коп. чистого прибутку.

Таблиця 3. - Оцінка ефективності використання оборотних засобів підприємства

\begin{tabular}{|l|l|c|c|c|c|c|}
\hline & Показники & 2013 & 2014 & 2015 & 2016 & Відхилення (+,-) \\
\hline 1. & Середньорічна вартість оборотних коштів, тис. грн. & 20878 & 20431 & 39844 & 37490 & $+16612,00$ \\
\hline 2. & Сума виручки, тис. грн. & 24262 & 24558 & 37550 & 53661 & $+29399,00$ \\
\hline 3. & Коефіцієнт оборотності оборотних засобів & 0,96 & 0,80 & 0,94 & 0,93 & $+0,03$ \\
\hline 4. & Тривалість обороту, днів в т.ч. & & & & & \\
\hline & оборотних коштів & 350,00 & 292,00 & 343,00 & 339,00 & -11 \\
\hline & запасів & 169,09 & 281,81 & 248,42 & 241,65 & $+72,56$ \\
\hline 5. & Коефіцієнт закріплення оборотних засобів & 0,86 & 0,83 & 1,06 & 0,70 & $-0,16$ \\
\hline 6. & Одноденний оборот звітного року, тис. грн. & 67,39 & 68,22 & 104,31 & 149,06 & $+81,66$ \\
\hline 7. & Отримано прибутку на 1 грн оборотних коштів, тис. грн. в т.ч. & & & & & \\
\hline & валової продукції & 0,43 & 0,27 & 0,38 & 0,58 & $+0,16$ \\
\hline & виручки & 1,16 & 1,20 & 0,94 & 1,43 & $+0,27$ \\
\hline & чистого прибутку & 0,13 & 0,13 & 0,16 & 0,23 & $+0,11$ \\
\hline
\end{tabular}

Джерело: власні розрахунки автора

В цілому у підприємства є можливість ефективно вести власну виробничу діяльність що позитивно впливає на прибутковість діяльності підприємства.

Оскільки раціональне та економічне використання оборотних активів має велике значення для економічного становища підприємства, то безумовно ми велику увагу приділили ефективності їх використання. В свою чергу основним показником ефективності використання є коефіцієнт оборотності т тривалість одного обороту. Проаналізувавши їх доцільно було б порекомендувати наступні заходи для підвищення їх ефективності:

- на стадії створення виробничих запасів - раціональне використання матеріальних ресурсів, удосконалення нормування, ліквідація нормативних запасів, налагодження роботи транспорту, оптимальний вибір постачальників та ін.

- на стадії незавершеного виробництва - скорочення тривалості виробничого циклу, впровадження прогресивної техніки і технологій, розвиток стандартизації та уніфікації, вдосконалення системи економічного стимулювання тощо.

- на стадії обігу - раціональна організація збуту продукції, прискорення документообороту, дотримання договірної платіжної дисципліни, використання маркетингових важелів активізації продажу (реклама) та ін.
Ефективність використання оборотних активів - це неодмінна умова існування підприємства в умовах конкурентної боротьби. Значною мірою вона залежить від досконалості методики аналізу ефективності їх використання, що в свою чергу дозволяє поліпшити якість управлінських рішень не тільки стосовно підвищення ефективності використання оборотних активів, а й ефективності діяльності підприємства в цілому.

При здійсненні основної діяльності підприємство вступає у фінансові відносини з державою щодо сплати податків і зборів. Змістом фінансової діяльності підприємства є забезпечення планомірного надходження і виплат грошових коштів, виконання платіжно-розрахункової дисципліни, досягнення оптимального співвідношення між власним і запозиченим капіталом та його ефективне використання. Обов'язковою умовою фінансової стійкості підприємства є дотримання конкретних співвідношень між фрінансовими потоками, які забезпечують покриття боргів і зобов'язань підприємств як у теперішньому, так і в майбутньому. Групування джерел фінансування оборотних активів підприємства відображено у таблиці 4.

Таблиця 4. - Джерела фінансування оборотних активів підприємства

\begin{tabular}{|c|c|c|c|c|c|}
\hline \multirow{2}{*}{ Показники } & \multicolumn{2}{|c|}{ Роки, тис.грн. } & \multirow{2}{*}{ Відхилення } \\
\cline { 2 - 4 } & 2015 & 2016 & 2017 & 2018 & (+,-) 2018 по відн. до 2015 рр \\
\hline 1. Власний капітал, в т. ч. : & 18753,0 & 21373,0 & 30183,0 & 36482,0 & 6299,0 \\
\hline статутний капітал & 21,0 & 21,0 & 21,0 & 21,0 & - \\
\hline інший додатковий капітал & 18732,0 & 21352,0 & 30162,0 & 36461,0 & 6299,0 \\
\hline 2. Позиковий капітал, в т. ч. & 10023,0 & 8030,0 & 24558,0 & 22417,0 & $-2141,0$ \\
\hline довгострокові зобов'язання & 395,5 & 687,0 & 3165,5 & 4714,0 & 1548,5 \\
\hline короткострокові кредити банків & 4900,0 & 733,0 & 1500,0 & 1800,0 & 300,0 \\
\hline поточні зобов'язання по розрахункам & 4727,5 & 6610,0 & 19892,5 & 15903,0 & $-3989,5$ \\
\hline Всього оборотних активів & 19413,0 & 19090,0 & 38387,0 & 34489,0 & $-3898,0$ \\
\hline
\end{tabular}

Джерело: власні розрахунки автора 
Слід зазначити, що у підприємстві відбувається стабільне зростання власного капіталу за рахунок додаткового капіталу та нерозподіленого прибутку, так у 2018 році відносно 2013 року цей показник зріс на17729,0 тис. грн., відносно 2017 року 6299,0 тис. грн. Досить позитивним моментом $€$ тенденція до зменшення позикового капіталу у 2016 році (на 2141,0 тис.грн. порівняно з 2017 роком) за рахунок зменшення поточних зобов'язань (3989,5 тис.грн. порівняно з 2017 роком), хоча довгострокові зобов'язання підприємства зростають як порівняно з 2015 так і порівняно з 2018 роком відповідно на 4318,5 та 1548.5 тис.грн.

Аналіз показників фрінансової стійкості дозволяє стверджувати що власний оборотний капітал для формування за- пасів зростає і досягає найвищого значення у 2015 році, однак зниження показника у 2016 році $є$ незначним і складає тільки 213 тис, хоча якщо порівняти показник 2016 року з 2013 - то його збільшення складає 4018 тис. грн.

Дослідження показали, що хоча підприємство досить ефективно використовує наявні оборотні ресурси, все жє резерви для підвищення ефективності їх використання. Відомо, що критерієм ефективності керування оборотними коштами служить фактор часу. Чим довше оборотні кошти перебувають в одній і тій же формі (грошовій або товарній), тим за інших рівних умов нижче ефективність їхнього використання, і навпаки.

\section{Cnuсок літератури:}

1. Аранчій В. А. Фінанси підприємств: Навч. посібник. - К.: ВД «Профресіонал», 2004. - 265 с.

2. Базілінська О.Я. Фінансовий аналіз: теорія та практика: навчальний посібник / О. Я. Базілінська. - 2-ге вид.. - К.: ЦУЛ, 2011. $-328 \mathrm{c}$.

3. Біла О. Г. Фінанси підприємств: навч. посіб. / О.Г. Біла - Львів: «Магнолія 2006», 2008. - 383 с.

4. Білик М.Д., Павловська О.В, Притуляк Н.М., Невмержицька Н.Ю. Фінансовий аналіз: Навч. посібник / Київський національний економічний ун-т ім. Вадима Гетьмана. — К. : КНЕУ, 2005. - 592с.

5. Верига Ю. А., Подольська В. О. Аналіз фінансового стану підприємства за фінансовою звітністю: Методичні рекомендації для практичних працівників. - Полтава: РВВ ПУСКУ, 2002. - 55 с.

6. Гайдис Надія Михайлівна. Фінансовий аналіз: Навч.-метод. посібник для студ. вищих навч. закл. / Національний банк України; Львівський банківський ін-т. - Л. : ЛБІ НБУ, 2006. - 414с.

7. Дєєва Надія Миколаївна, Дедіков Олексій Іванович. Фінансовий аналіз: Навч.-метод. посібник для студ. вищих навч. закл. / Дніпропетровська держ. фінансова академія. - Д. : ДДФА, 2006. - 380с.

\section{References:}

1. Aranchii V.A. (2004), Finances of enterprises: textbook. Publishing house «Professional», 265 p.

2. Bazilinska O. (2011), Financial analysis: theory and practice: study guide. 2nd ed, 328 p.

3. Bila O.G. (2008), Finance: textbook. Lviv, Ukraine, 383 p.

4. Bilyk M. D., Pavlovskaya O.V., Prytulyak N.M., Nevmerghitska N. Y. (2005), Financial analysis: textbook, KNEU, Kyiv,Ukraine, 592p.

5. Veriga Y.A. (2002), "Town at the analysis of the financial condition of the prise for financial reporting". Publishing house "START-UP", $55 \mathrm{p}$. $414 \mathrm{p}$.

6. Gajdis N.M. (2006), Financial analysis: textbook-method, The National Bank of Ukraine; Lviv banking Institute, Lviv, Ukraine,

7. Deeva M.N., Dedikov A. I.(2006), Financial analysis: textbook-method, DDFA, Dnipro, Ukraine, 380 p

Tereshchenko Svitlana, Dr, Associate Professor, Sumy National Agrarian University (Sumy, Ukraine)

Feday Valery, student, Sumy National Agrarian University (Sumy, Ukraine)

Effective use of current assets by enterprise

In today's business environment, each enterprise places the main emphasis on addressing the issues of stability of operation and profit maximization. In order to achieve these goals, we need a properly selected, clear and effective asset management policy for the enterprise, in which working capital plays a significant role. The relevance of the current problem of working capital management is also due to the fact that the efficiency of their formation, regulation and use depends on the optimality of the level of liquidity, solvency and, as a consequence, financial stability of the enterprise. Lack of working capital puts the company on the path of bankruptcy, which causes them to think about improving their management system. The lack of funds and their surplus have a significant impact on the enterprise, causing disruptions in the production or supply of raw materials, which reduce the expected profit. That is why it is very important to accelerate the attraction of working capital both from internal and external sources. Qualified cash management enables interested parties (external and internal users) to make certain optimal management decisions that can significantly affect the end result of the enterprise's financial and economic activities in the future.

Since the rational and economic use of current assets is of great importance for the economic situation of the enterprise, we have undoubtedly paid great attention to the efficiency of their use. In turn, the main indicator of efficiency of use is the turnover rate and the duration of one revolution. Having analyzed them, it would be advisable to recommend the following measures to improve their effectiveness:

- at the stage of creation of production stocks - rational use of material resources, improvement of normalization, elimination of normative stocks, adjustment of work of transport, optimum choice of suppliers, etc.

- at the stage of work in progress - shortening the duration of the production cycle, the introduction of advanced technology and technologies, the development of standardization and unification, the improvement of the system of economic incentives and more. 
- at the stage of circulation - rational organization of sales of products, acceleration of document circulation, adherence to contractual payment discipline, use of marketing levers of sales activation (advertising), etc.

The use of current assets is an indispensable condition for the existence of an enterprise in a competitive environment. To a large extent, it depends on the perfection of the methods of analysis of the effectiveness of their use, which in turn allows to improve the quality of management decisions not only to increase the efficiency of the use of current assets, but also the efficiency of the enterprise as a whole.

In carrying out its main activity, the company enters into financial relations with the state in payment of taxes and fees. The content of the financial activity of the company is to ensure the planned receipt and payment of funds, the implementation of payment and settlement discipline, to achieve the optimal ratio between equity and borrowed capital and its effective use. An indispensable condition for an enterprise's financial soundness is compliance with specific relationships between the financial flows that cover the debts and liabilities of the enterprise, both in the present and in the future.

Keywords: assets, financial results, current assets, working capital, working capital, working capital, sources of financing

Дата надходження до редакції: 20.01.2019 р. 